\title{
The Cosheston Group (Lower Old Red Sandstone) in southwest Wales: age, correlation and palaeobotanical significance
}

\author{
C. H. WELLMAN*†, R. G. THOMAS $\ddagger$, D. EDWARDS* \& P. KENRICK§ \\ * Department of Earth Sciences, University of Wales, Cardiff, P.O. Box 914, Cardiff CF1 3YE, UK \\ $\dagger$ Centre for Palynology, University of Sheffield, Dainton Building, Brook Hill, Sheffield S3 7HF, UK \\ \$ Apartment 301, 10036 117th Street, Edmonton, Alberta T5K 1X 2, Canada \\ $\S$ Department of Palaeontology, The Natural History Museum, Cromwell Road, London SW7 5BD, UK
}

(Received 19 December 1996; accepted 17 November 1997)

\begin{abstract}
Upper Silurian-Lower Devonian 'Lower Old Red Sandstone' facies deposits cropping out in southwest Wales are poorly age-constrained and difficult to correlate. Spore assemblages have been recovered from sequences of these deposits belonging to the lower part of the Cosheston Group. The spore assemblages are equated with the breconensis-zavallatus and polygonalis-emsiensis Spore Assemblage Biozones and indicate an early Devonian age (late Gedinnian (late Lochkovian)-Siegenian (Pragian)). The new biostratigraphical data enable correlation of the lower part of the Cosheston Group with the Senni Beds from the main outcrop of the Lower Devonian in South Wales and the Welsh Borderland. In addition, the new age data and stratigraphical correlation place important plant megafossil assemblages from the Cosheston Group and Senni Beds in a more secure stratigraphical framework, thus facilitating comparisons with other Lower Devonian plant megafossil assemblages and enhancing palaeobotanical understanding. Evidence from palynofacies analysis supports sedimentological interpretations which suggest that the 'Lower Old Red Sandstone' facies deposits belonging to the Cosheston Group accumulated in a continental fluviatile environment.
\end{abstract}

\section{Introduction}

The 'Lower Old Red Sandstone' deposits of southwest Wales comprise a thick sequence of predominantly continental fluviatile deposits that accumulated in the AngloWelsh Basin during the Caledonian orogeny (Figs 1,2). Age determination and stratigraphic correlation of these deposits has traditionally been hampered by the paucity of biostratigraphically useful fossils, the structural complexity of the area and difficulties of lithostratigraphical correlation. The latter is problematic because 'Old Red Sandstone' facies deposits commonly exhibit extensive lateral and vertical facies variation. This report describes spore assemblages recovered from part of the 'Lower Old Red Sandstone' sequence of southwest Wales (the lower part of the Cosheston Group) which permit accurate age determinations and stratigraphical correlation with the main outcrop of South Wales and the Welsh Borderland. Furthermore, the new biostratigraphical information provides age constraints for important plant megafossil assemblages recovered from the Cosheston Group and its correlatives. Such integrated palynological and palaeobotanical analyses of plant microfossil and megafossil assemblages provide important insights into the nature of early Devonian terrestrial vegetation.

\section{Geological setting}

The 'Lower Old Red Sandstone' deposits of the AngloWelsh Basin represent a post-orogenic molasse sequence,

$\dagger$ Author for correspondence: C.Wellman@sheffield.ac.uk comprising a thick succession of predominantly continental fluviatile deposits, which accumulated during the Caledonian orogeny. The environment of deposition is interpreted as an extensive alluvial plain traversed by streams and rivers flowing out of the Caledonian uplands to the north and draining into the Rheic Ocean to the south (Allen, 1979, 1985; Bluck, Cope \& Scrutton, 1992). The 'Lower Old Red Sandstone' deposits in southwest Wales are separated from the main outcrop by the Benton Fault, and are divided into two zones of contrasting sequence by the Ritec Fault (see Powell, 1987, and references therein). These deposits are considered to have accumulated in an area of complex relief with syn-depositional faulting (Allen \& Williams, 1978; Allen, 1985; Powell, 1987). An outcrop map and stratigraphical successions of the 'Lower Old Red Sandstone' in the Anglo-Welsh Basin are illustrated in Figures 1 and 2 respectively.

South of the Ritec Fault, the 'Lower Old Red Sandstone' deposits are up to $1500 \mathrm{~m}$ in thickness (Dixon, 1921, 1933a, 1933b; King, 1934; Owen et al. 1971; Williams, 1971; Williams, Allen \& Marshall, 1982) (Fig. 2). They are divided into the Milford Haven Group (443-995 m) which is unconformably overlain by the Ridgeway Conglomerate Formation $(0-427 \mathrm{~m})$. The Milford Haven Group south of the Ritec Fault has in places been dated using spores (Richardson \& Lister, 1969) and fish (White, 1938, 1946, 1950) (Fig. 2). The Ridgeway Conglomerate, however, is unfossiliferous. North of the Ritec Fault, the 'Lower Old Red Sandstone' deposits cropping out between the Ritec and Benton faults are up to $4000 \mathrm{~m}$ in thickness (Strahan et al. 1914; Cantrill et al. 1916; Allen \& Williams, 1978; Allen, 


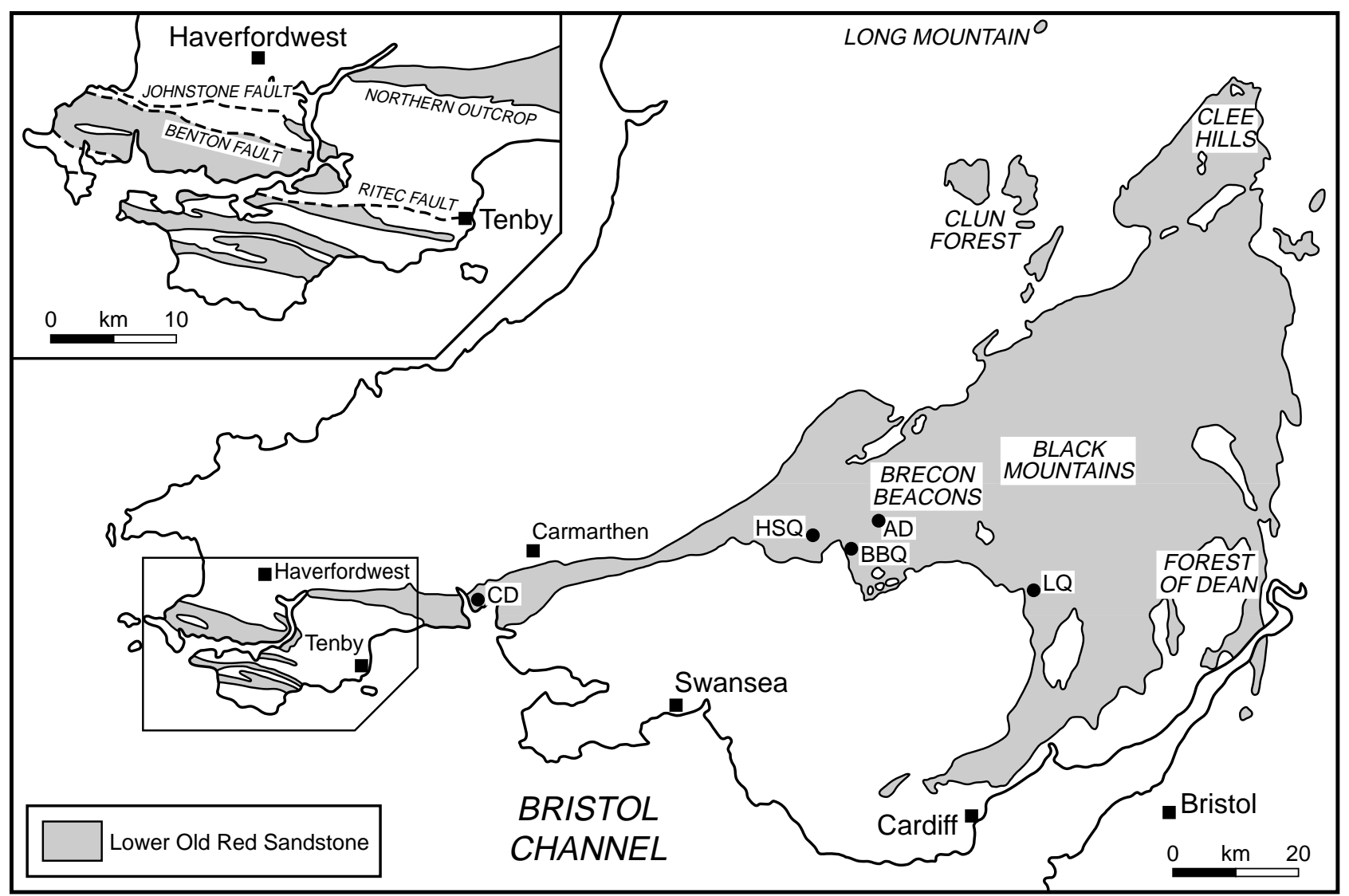

Figure 1. Outcrop of 'Lower Old Red Sandstone' deposits in South Wales and the Welsh Borderland. The inset is an enlargement of the area of southwest Wales. The location of plant megafossil localities in the Senni Beds is indicated $(\mathrm{AD}=\mathrm{Allt} \mathrm{Ddu} ; \mathrm{BBQ}=\mathrm{Brecon}$ Beacons (Storey Arms) Quarry; CD = Craig Ddu; HSQ = Heol Senni Quarry; LQ = Llanover Quarry).

Thomas \& Williams, 1982) (Fig. 2). They are divided into the Milford Haven Group (1850-2637 m) which is conformably overlain by the Cosheston Group (1505-1800 $\mathrm{m})$. The Milford Haven Group north of the Ritec Fault has in places been dated using invertebrates, fish and plant remains (Allen \& Williams, 1978) (Fig. 2). Plant remains are present in the Cosheston Group but are of limited biostratigraphical value (Strachan et al. 1914; Cantrill et al. 1916; R. Thomas, unpub. Ph.D. thesis, Univ. Bristol, 1978; P. Kenrick, unpub. Ph.D. thesis, Univ. Wales, 1988).

The Townsend Tuff Bed is an important marker horizon which enables 'Lower Old Red Sandstone' sequences either side of the Ritec Fault to be correlated and tied in with the main outcrop of the Anglo-Welsh Basin (Allen \& Williams, 1981, 1982). The Townsend Tuff Bed, which comprises lithologically distinctive and laterally extensive air-fall tuffs, has also been proposed as the local base of the Devonian System in the Anglo-Welsh Basin. However, above the Townsend Tuff Bed, age determination and stratigraphical correlation are problematic due to the paucity of biostratigraphically useful fossils, the complex tectonics of the region and the difficulties of lithological correlation due to extensive lateral and vertical facies variation.

The Cosheston Group is the uppermost group in the
'Lower Old Red Sandstone' sequence south of the Ritec Fault. It conformably succeeds the Milford Haven Group and is unconformably overlain by the 'Upper Old Red Sandstone' Skrinkle Sandstone Group. The Cosheston Group is $1505-1800 \mathrm{~m}$ in thickness and consists of green intraformational conglomerates, green sandstones with subordinate red sandstones, and green or red siltstones, arranged in fining-upward sequences. The upper part of the group tends to be coarser grained and red brown and contains breccias and conglomerates composed of a variety of lithologies including intrusive and extrusive igneous rocks, metamorphic rocks and various sandstones. Interestingly, Thomas (R. Thomas, unpub. Ph.D. thesis, Univ. Bristol, 1978) noted that palaeocurrent direction in the Cosheston Group appears to be predominantly from the west. The Cosheston Group has been divided into five formations (R. Thomas, unpub. Ph.D. thesis, Univ. Bristol, 1978; Thomas in Friend \& Williams, 1978; Allen, Thomas \& Williams, 1982) (Figs 2, 3).

\section{Cosheston Group spore assemblages}

\section{3.a. Methods}

Samples were collected from throughout the Cosheston Group sequence and were palynologically processed using standard $\mathrm{HCl} / \mathrm{HF}$ acid maceration techniques. The 


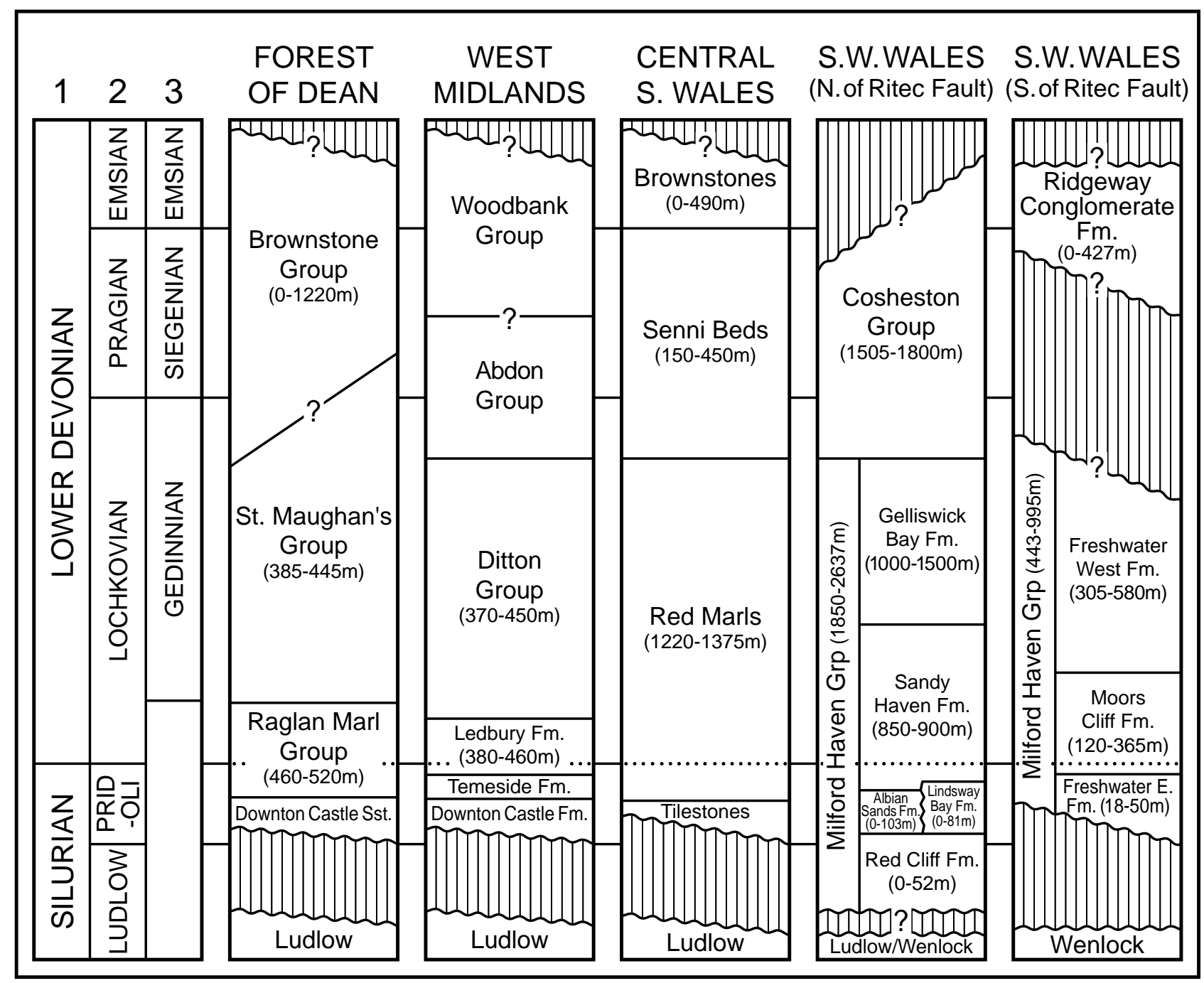

Figure 2. Correlation chart for 'Lower Old Red Sandstone' sequences in the Anglo-Welsh Basin (based on Friend \& Williams, 1978, with additional information from Allen, 1979, 1985, and Allen \& Williams, 1982). Column $1=$ Series; $2=$ Standard Epoch/Stages; $3=$ Ardennes-Rhenish Stages. The dotted line at the Silurian/Devonian boundary represents the Townsend Tuff. Age correlations are based on the limited available biostratigraphical information derived from studies of vertebrate remains and dispersed spores (see text).

organic residues were oxidized for $\frac{3}{4}-3$ hours in saturated Schulze's solution in order to clear them for analysis using light microscopy. Productive samples were confined to the Llanstadwell, Burton Cliff, Mill Bay and lowermost Lawrenny Cliff formations (see Fig. 3, Table 1). Spore identifications were based on detailed logging of residues derived from 29 samples (13 localities), which incorporated the maximum stratigraphical coverage and the best preserved samples (see Table 2). All slides are stored in the Department of Geology of the National Museum of Wales, Cardiff.

\section{3.b. Description of the spore assemblages}

Eighty-eight spore taxa were recognized in the Cosheston Group spore preparations (R. Thomas, unpub. Ph.D. thesis, Univ. Bristol, 1978). The distribution and abundances of important taxa/morphotypes are outlined in Tables 2 and 3 respectively. The spores are distributed in two distinctive spore assemblages: an 'older' assemblage comprising the spore preparations from the Llanstadwell Formation and a 'younger' assemblage comprising the spore preparations from the Burton Cliff, Mill Bay and lowermost Lawrenny Cliff formations. In the following account the quoted percentages are derived from counts (see Table 3) and are either expressed as ranges or in terms of minimum(mean) maximum values.

Both the 'older' and 'younger' spore assemblages are dominated by smooth-walled miospores (between 60 and $76 \%$ ) that are either retusoid, crassitate or patinate and can be accommodated in the genera Retusotriletes, Ambitisporites and Archaeozonotriletes. Some of the species of Retusotriletes have proximal thickenings associated with the trilete marks (e.g. Fig. 4f, g). Apiculate retusoid spores are common in the 'older' assemblage 
Table 1. Locality details for productive palynological samples (see Fig. 3)

\begin{tabular}{|c|c|c|c|}
\hline Samples & Formation & Grid reference & Location \\
\hline NN3 \& 15 & Llanstadwell Fm. & SM934059 & $\begin{array}{l}\text { Siltstones at the base of the Llanstadwell Fm. in the } \\
\text { section exposed in the railway cutting at Newton Noyes. }\end{array}$ \\
\hline WPW1 & Llanstadwell Fm. & SM96810583 & $\begin{array}{l}\text { Siltstone } c .1 \mathrm{~m} \text { above the base of the Llanstadwell Fm. } \\
\text { exposed in the section on the western shore of Westfield } \\
\text { Pill. }\end{array}$ \\
\hline WP4 \& 25 & Llanstadwell Fm. & c. SM937043 & Siltstones exposed in the coastal section west of Wear Point. \\
\hline MB5, 8, $11 \&$ RT25 & Llanstadwell Fm. & SM95650558 & $\begin{array}{l}\text { Siltstones 7, } 27 \text { and } 43 \mathrm{~m} \text { above the base of the section } \\
\text { exposed in Muscle Bridge Quarry. The quarry is located } \\
\text { beside the B } 4325 \text { road c. } 250 \mathrm{~m} \text { southeast of Muscle Bridge } \\
\text { Hamlet. }\end{array}$ \\
\hline HPE $1 \& 24$ & Llanstadwell Fm. & SM972043 & $\begin{array}{l}\text { Siltstone } 59 \mathrm{~m} \text { below the junction between the Llanstadwell } \\
\text { and Burton Cliff formations exposed in the Hobbs Point } \\
\text { East coastal section. }\end{array}$ \\
\hline HPE43, $44 \& 47$ & Burton Cliff Fm. & SM970042 & $\begin{array}{l}\text { Siltstone } 6 \mathrm{~m} \text { above the junction between the Llanstadwell } \\
\text { and Burton Cliff formations exposed in the Hobbs Point } \\
\text { East coastal section. }\end{array}$ \\
\hline $\mathrm{BC} 2 \& 8$ & Burton Cliff Fm. & c. SM988051 & Siltstones exposed in the coastal section at Burton Cliff. \\
\hline CBP4 & Mill Bay Fm. & c. SM974046 & $\begin{array}{l}\text { Siltstones exposed in the coastal section exposed near } \\
\text { Cheddar Bridge Pier. }\end{array}$ \\
\hline CPW4 \& 10 & Mill Bay Fm. & c. SM983042 & $\begin{array}{l}\text { Siltstones exposed in the coastal section on the west shore of } \\
\text { Cosheston Pill. }\end{array}$ \\
\hline $\mathrm{BC} 24$ & Mill Bay Fm. & c. SM990052 & Siltstones exposed in the coastal section at Burton Cliff. \\
\hline MBW17, 45, 69, $84 \& 121$ & Mill Bay Fm. & c. SN000050 & Siltstones exposed in the Mill Bay West coastal section. \\
\hline MBE9, $22 \& 35$ & Mill Bay Fm. & c. SN005051 & Siltstones exposed in the Mill Bay East coastal section. \\
\hline MBE46 & Lawrenny Cliff Fm. & c. SN007057 & Siltstones exposed in the Mill Bay East coastal section. \\
\hline
\end{tabular}

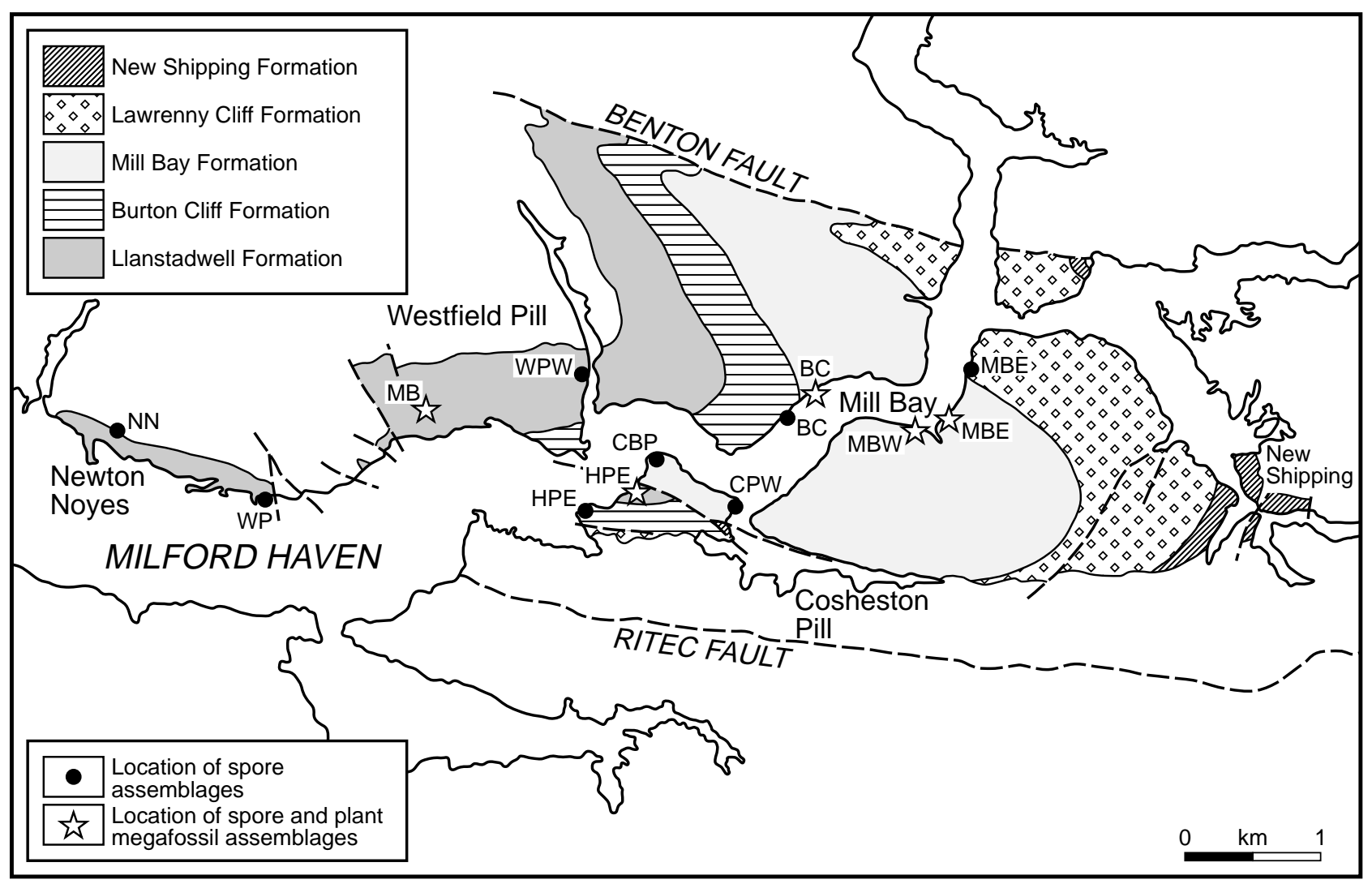

Figure 3. Geological map of the Cosheston Group outcrop in southwest Wales. Location of spore and plant megafossil assemblages indicated (see Tables 1 and 4): BC = Burton Cliff; CBP = Cheddar Bridge Pier; CPW = Cosheston Pill (western shore); HPE = Hobbs Point East; MB = Muscle Bridge Quarry; MBE = Mill Bay East; MBW = Mill Bay West; NN = Newton Noyes; WP = Wear Point; WPW $=$ Westfield Pill (western shore). 


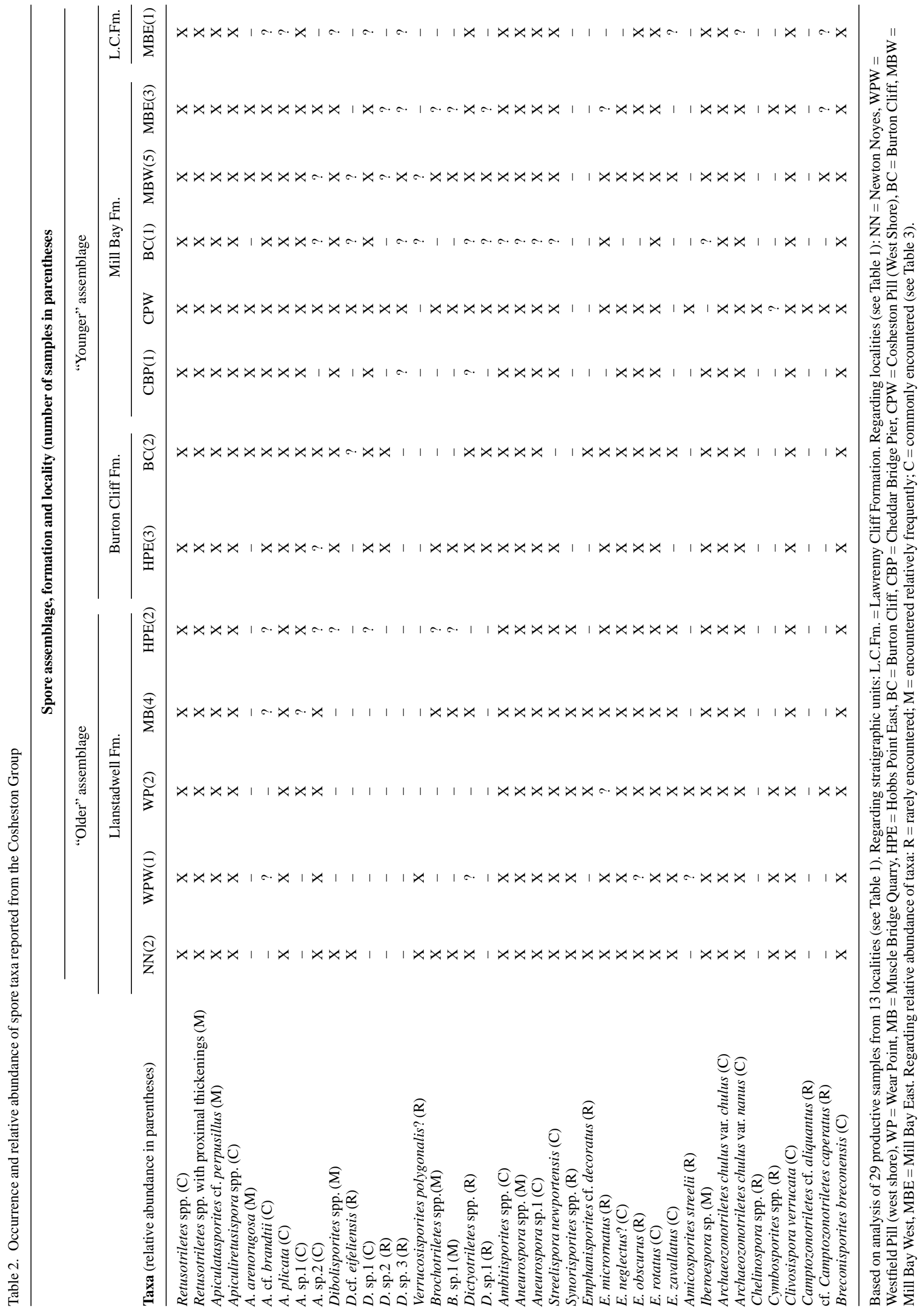




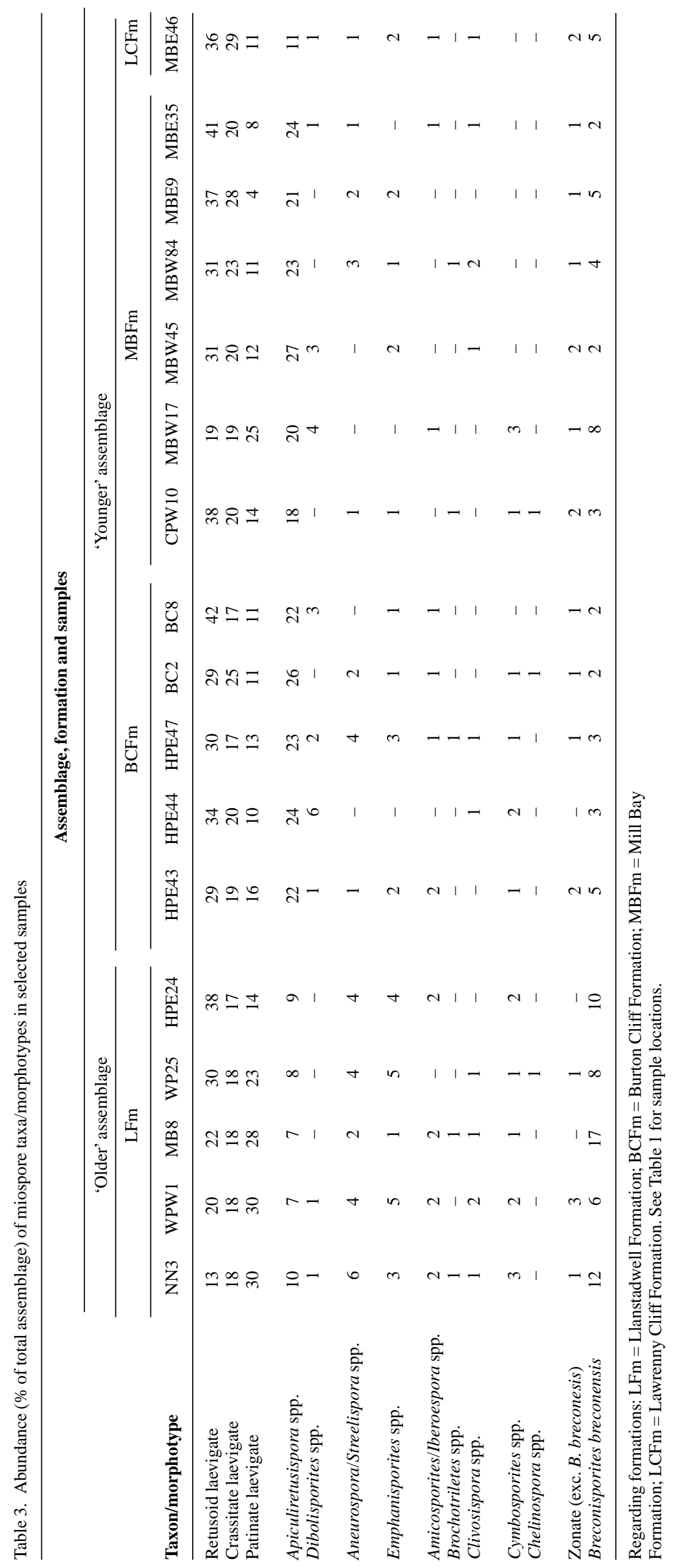


(7(8)10\%) but abundant in the 'younger' assemblage (11(22)27\%), and belong to the genera Apiculiretusispora and Dibolisporites, and include the taxa A. arenorugosa McGregor, 1973; A. cf. brandtii Streel, 1964; A. plicata (Allen) Streel, 1967 and D. cf. eifeliensis (Lanninger) McGregor, 1973. There are a number of ornamented crassitate spores which belong to Aneurospora, Streelispora and Synorisporites, and include Streelispora newportensis (Chaloner \& Streel) Richardson \& Lister, 1969, but in counts these never comprise more than $6 \%$ of the total spores. Laevigate patinate spores (Archaeozonotriletes chulus) are common, but ornamented patinate spores are always rare, although Chelinospora and Cymbosporites are represented. Spores belonging to Emphanisporites comprise up to $5 \%$ of the total spores and include $E$. cf. decoratus Allen, 1965; E. micrornatus Richardson \& Lister, 1969; E. neglectus? Vigran, 1964; E. obscurus McGregor, 1961; E. rotatus McGregor, 1961 emend. McGregor, 1973, and the biostratigraphically important species E. zavallatus Richardson et al. 1982 (Fig. 5e, i). Other ornamented spores include Brochotriletes spp.; Dictyotriletes spp.; Verrucosisporites polygonalis? Lanninger, 1968; Amicosporites streelii Steemans, 1989; Iberoespora sp. and Clivosispora verrucata McGregor, 1973, but these taxa are always rare. Zonate spores such as Camptozonotriletes cf. aliquantus Allen, 1965 and cf. $C$. caperatus McGregor, 1973 are rare, but the biostratigraphically important bizonate species Breconisporites breconensis Richardson et al. 1982 is abundant in the 'older' assemblage (6(11)17\%), although less common in the 'younger' assemblage (2(4)8\%).

The 'older' and 'younger' spore assemblages differ in terms of taxon/morphotype composition and abundance. In terms of composition the 'younger' assemblage is more diverse and contains a number of taxa not present in the 'older' assemblage, namely: Apiculiretusispora arenorugosa, A. cf. brandtii, Dibolisporites spp.1-3, and cf. Camptozonotriletes aliquantus. In terms of overall composition, the older assemblage is dominated by laevigate spores, but Breconisporites breconensis is particularly abundant, and species of Emphanisporites with fine proximal ribbing, small Apiculiretusispora spp. Streelispora newportensis and Emphanisporites zavallatus are relatively common. The 'younger' assemblage differs because apiculate spores, including those with biform sculpture (Dibolisporites spp.), are far more abundant. Common apiculate spores include Apiculiretusispora arenorugosa, A. cf. brandtii, A. plicata, A. sp.1 and A. sp.2. Some of these taxa are present, but far less abundant, in the 'older' assemblage. Dibolisporites is extremely rare in the 'older' assemblage but is commonly present in the 'younger' assemblage where it is represented by Dibolisporites cf. eifeliensis and Dibolisporites spp.1-3.

\section{3.c. Spore biostratigraphy and age determination}

Spore zonation schemes for the Lower Devonian have been proposed by Richardson \& McGregor (1986) and
Streel et al. (1987) (Fig. 6). The 'older' Cosheston Group assemblage is assigned to the breconensis-zavallatus Spore Assemblage Biozone of Richardson \& McGregor (1986). It contains both of the nominal species and, in terms of taxon composition and spore morphotype abundance, is very similar to previously described spore assemblages attributed to this Spore Assemblage Biozone, particularly those described from the Brecon Beacons and Ardennes-Rhenish region (Richardson et al. 1982; Richardson \& McGregor, 1986; Steemans, 1989). The 'younger' Cosheston Group assemblage is assigned to the polygonalis-emsiensis Spore Assemblage Biozone of Richardson \& McGregor (1986). Neither of the two nominal species for the zone (Verrucosisporites polygonalis and Dictyotriletes emsiensis) are present. However, Richardson \& McGregor (1986) note that these taxa are also absent from spore assemblages belonging with the polygonalis-emsiensis Spore Assemblage Biozone from the Brecon Beacons of South Wales. In terms of taxon composition and spore morphotype abundance the 'younger' Cosheston Group assemblage exhibits many of the characteristics typical of spore assemblages assigned to the polygonalis-emsiensis Spore Assemblage Biozone, for example, the occurrence and proliferation of Dibolisporites, the paucity of spores with proximal interradial papillae, and the abundance and diversity of Brochotriletes, Dictyotriletes, coarsely sculptured Emphanisporites and, most notably, Apiculiretusispora. Furthermore, in addition to the nominal species, Richardson \& McGregor considered thirteen other species characteristic of the polygonalis-emsiensis zone. Identical, or closely similar, forms of a number of these taxa are present in the 'younger' Cosheston Group assemblage, namely: A. arenorugosa, A. cf. brandtii, A. plicata, $B$. breconensis, cf. C. caperatus, $C$. verrucata and $E$. cf. decoratus. In the scheme of Richardson \& McGregor (1986) the 'older' Cosheston Group assemblage is excluded from the preceding micrornatus-newportensis Spore Assemblage Biozone because of the occurrence of B. breconensis and E. zavallatus. However, certain taxa characteristic of the micrornatus-newportensis Spore Assemblage Biozone are present in the 'older' Cosheston Group assemblage and it is possible that some of these spores may have been reworked. The 'younger' Cosheston Group assemblage is excluded from the succeeding annulatus-sextantii Spore Assemblage Biozone because of: (1) the absence of the nominal species (Emphanisporites annulatus and Camarazonotriletes sextantii) and other species characteristic of this zone; (2) differences in general morphological characteristics.

The Cosheston Group spore assemblages can be placed within the BZ and PoW Oppel Zones of Streel et al. (1987), which are more or less identical to the breconensis-zavallatus and polygonalis-emsiensis Spore Assemblage Biozones of Richardson \& McGregor (1986) (Fig. 6). A minor difference between the two zonation schemes is that Dibolisporites wetteldorfensis replaces Dictyotriletes emsiensis as a nominal species for the PoW 

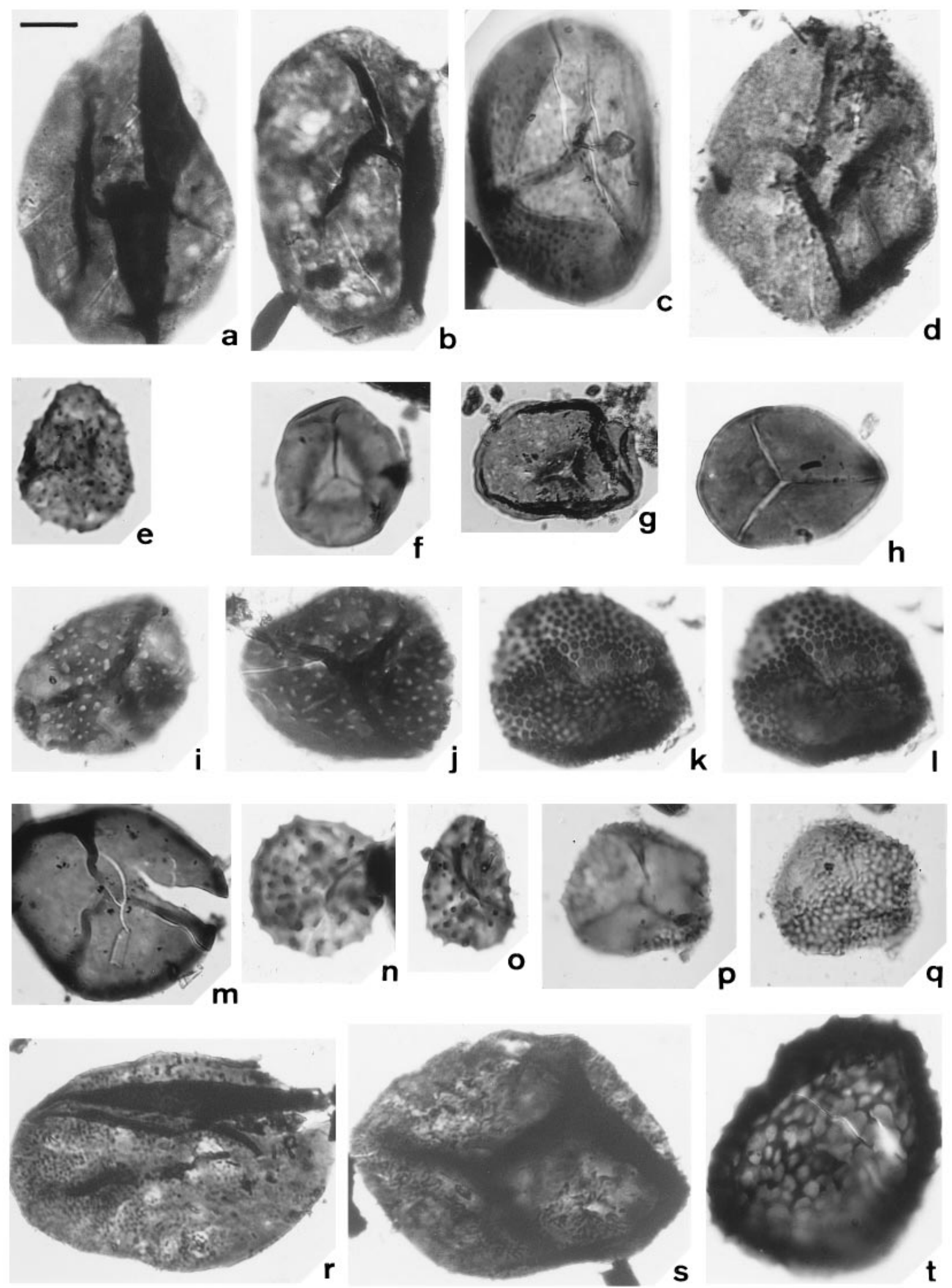

Figure 4. Spores from the Cosheston Group (scale bar in top left hand corner equals $10 \mu \mathrm{m}$, except in (a), (b) and (s) where it equals $16 \mu \mathrm{m},(\mathrm{g})$ where it equals $20 \mu \mathrm{m}$ and (r) where it equals $13 \mu \mathrm{m}$ ). E.F. No. = England Finder Number. (a) Apiculiretusispora arenorugosa McGregor, 1973. Sample CPW4, Slide NMW97.22G.3, E.F. No. N36/2, Mill Bay Formation, Cosheston Pill (west shore); (b) Apiculiretusispora arenorugosa McGregor, 1973. Sample CPW4, Slide NMW97.22G.2, E.F. No. K54/4, Mill Bay Formation, Cosheston Pill (west shore); (c) Apiculiretusispora sp.1. Sample CPW4, Slide NMW97.22G.2, E.F. No. M51, Mill Bay Formation, Cosheston Pill (west shore); (d) Dibolisporites sp.2. Sample CPW4, Slide NMW97.22G.2, E.F. No. Q33/3, Mill Bay Formation, Cosheston Pill (west shore); (e) Apiculatasporites cf. perpusillus (Naumova) McGregor, 1973. Sample NN3, Slide NMW97.22G.8, 
Oppel Zone in the scheme of Streel et al. (1987). One of the reasons for this substitution is that the first appearance of V. polygonalis and D. emsiensis is variable: V. polygonalis occurs earlier than D. emsiensis in Gaspé, Canada (McGregor, 1973), but later than D. emsiensis in Ontario, Canada (McGregor \& Camfield, 1976) and the ArdennesRhenish region (Steemans, 1989; Richardson \& McGregor, 1986). In the scheme of Streel et al. (1987) the Oppel zones are divided into interval zones based on the first appearance of selected taxa. None of the relevant taxa are present in the Cosheston Group spore assemblages so designation to interval zones is difficult. However, Amicosporites streelii which occurs throughout the Cosheston Group spore assemblages is not known above the $\operatorname{Pa}(\alpha)$ interval zone (Steemans, 1989). This suggests that the $\mathrm{Pa}(\beta)$ and $\mathrm{Su}$ interval zones, the uppermost interval zones of the PoW Oppel Zone, may not be represented in the Cosheston Group spore-bearing strata (assuming no reworking of A. streelii in the Cosheston Group).

There are considerable difficulties involved with correlation between Upper Silurian-Lower Devonian sequences in Britain, the Ardennes-Rhenish region and the type area of Bohemia because the deposits are represented by different facies and therefore contain different groups of fossils (see Richardson, Rasul \& Al-Ameri, 1981; Richardson, 1984; Richardson, Ford \& Parker, 1984; Steemans, 1989). The British sequences can be correlated with those in the Ardennes-Rhenish region using spore biostratigraphy (e.g. Richardson et al. 1982). However, the Ardennes-Rhenish sequences have to be correlated with the type Bohemian sequence via crosscorrelation using different fossil groups (e.g. spores, chitinozoans, fish, invertebrates) between intermediary sequences in Brittany and Podolia. Thus a basic intercorrelation between the four areas is achieved (e.g. Richardson, Rasul \& Al-Ameri, 1981; Streel et al. 1987; Steemans, 1989), although precise correlation between the type Bohemian stages (Lochkovian and Pragian) and those used in the Ardennes-Rhenish region (Gedinnian and Siegenian) has yet to be accomplished. Nevertheless, current data suggest that the breconensis-zavallatus/BZ zone, and hence the 'older' spore assemblages from the
Llanstadwell Formation, are of late Lochkovian (late Gedinnian)-earliest Pragian (?earliest Siegenian) age, and the polygonalis-emsiensis/PoW zone, and hence the 'younger' spore assemblages from the Burton Cliff, Mill Bay and lowermost Lawrenny Cliff formations, are of early Pragian (?early Siegenian)-latest Pragian (?latest Siegenian) or possibly earliest Emsian age (Richardson \& McGregor, 1986; Streel et al. 1987; Steemans, 1989).

\section{Geological significance}

\section{4.a. Stratigraphical correlation}

Information on the spore biostratigraphy of the Cosheston Group permits correlation of these deposits with those of the main outcrop of the 'Lower Old Red Sandstone' in South Wales and the Welsh Borderland. Spore assemblages from the Senni Beds of the main outcrop have been investigated by Hassan (A. Hassan, unpub. PhD thesis, Univ. London, 1982) and the main biostratigraphical conclusions summarized in Richardson et al. (1982) and Richardson \& McGregor (1986). Hassan and Richardson are currently preparing a detailed report on the spore systematics and biostratigraphical interpretation of sporomorph assemblages from the Senni Beds.

Richardson et al. (1982) and Richardson \& McGregor (1986) report that the lowest spore assemblages recovered from the Senni Beds occur 3-4 $\mathrm{m}$ above the base of the unit, and belong to the breconensis-zavallatus zone, with spore assemblages belonging with this zone present in the succeeding 64 and $90 \mathrm{~m}$ of the unit in the Black Mountains and Brecon Beacons respectively. However, the remainder of the Senni Beds contain spore assemblages belonging to the polygonalis-emsiensis zone (Fig. 7). Spore assemblages have not been reported from the Brownstones Group which overlies the Senni Beds.

The 'older' spore assemblages from the Llanstadwell Formation (Cosheston Group) belong with the breconensis-zavallatus zone and these strata can therefore be correlated with the lower part of the Senni Beds (Fig. 7). The 'younger' spore assemblages from the overlying Burton Cliff, Mill Bay and lowermost Lawrenny Cliff formations (Cosheston Group) belong with the

E.F. No. S66/1, Llanstadwell Formation, Newton Noyes; (f) Retusotriletes with proximal thickening. Sample WP25, Slide NMW97.22G.13, E.F. No. L23, Llanstadwell Formation, Wear Point; (g) Retusotriletes with proximal thickening. Sample CPW4, Slide NMW97.22G.2, E.F. No. F47, Mill Bay Formation, Cosheston Pill (west shore); (h) Ambitisporites sp. Sample WP25, Slide NMW97.22G.14, E.F. No. N32/4, Llanstadwell Formation, Wear Point; (i) Brochotriletes sp.1. Sample CPW4, Slide NMW97.22G.3, E.F. No. D25, Mill Bay Formation, Cosheston Pill (west shore); (j) Brochotriletes sp.1. Sample CPW4, Slide NMW97.22G.3, E.F. No. N45/1, Mill Bay Formation, Cosheston Pill (west shore); (k, 1) Verrucosisporites polygonalis? Lanninger, 1968. Sample NN3, Slide NMW97.22G.7, E.F. No. E50, Llanstadwell Formation, Newton Noyes. View of proximal and distal surface respectively; (m) Ambitisporites sp. Sample MB8, Slide NMW97.22G.18, E.F. No. X47/4, Llanstadwell Formation, Muscle Bridge Quarry; (n) Aneurospora sp. Sample WPW1, Slide NMW97.22G.19, E.F. No. W20/3, Llanstadwell Formation, Westfield Pill (west shore); (o) Aneurospora sp. Sample NN3, Slide NMW97.22G.7, E.F. No. U34, Llanstadwell Formation, Newton Noyes; (p, q) Dictyotriletes sp.1. Sample NN3, Slide NMW97.22G.7, E.F. No. X43, Llanstadwell Formation, Newton Noyes. View of proximal and distal surface respectively; (r) Dibolisporites sp.1. Sample CPW4, Slide NMW97.22G.3, E.F. No. V17/2, Mill Bay Formation, Cosheston Pill (west shore); (s) Dibolisporites sp.1. Sample CPW4, Slide NMW97.22G.3, E.F. No. N38/2, Mill Bay Formation, Cosheston Pill (west shore); (t) Brochotriletes sp. Sample RT25, Slide NMW97.22G.20, E.F. No. U49, Llanstadwell Formation, Muscle Bridge Quarry. 

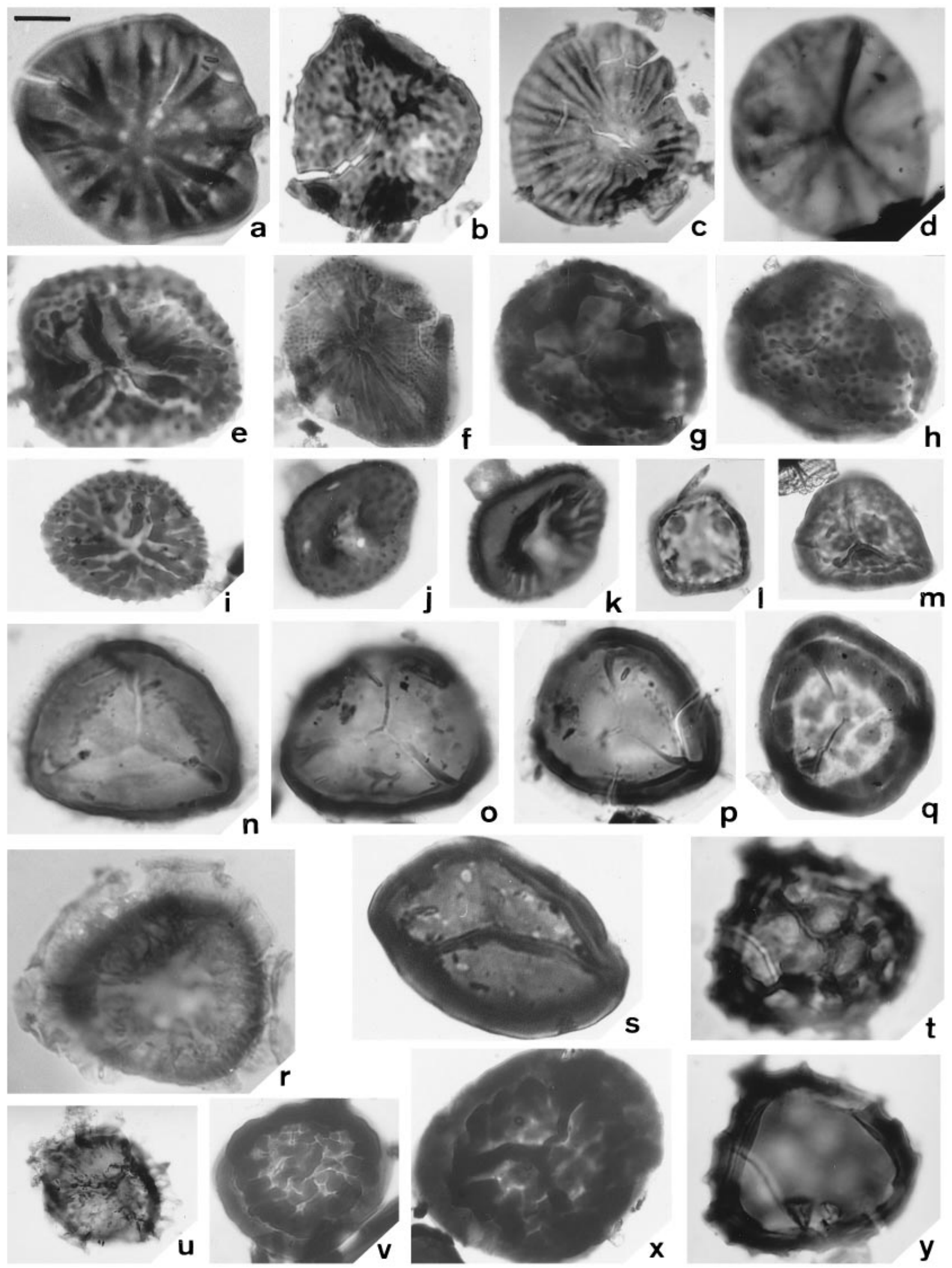

Figure 5. Spores from the Cosheston Group [scale bar in top left hand corner equals $10 \mu \mathrm{m}$, except in (u) where it equals $20 \mu \mathrm{m}$ ]. E.F. No. = England Finder Number. (a) Emphanisporites rotatus McGregor emend. McGregor, 1973. Sample WP25, Slide NMW97.22G.12, E.F. No. Q56/4, Llanstadwell Formation, Wear Point; (b) Emphanisporites cf. decoratus Allen, 1965. Sample WP25, Slide NMW97.22G.10, E.F. No. E44, Llanstadwell Formation, Wear Point; (c) Emphanisporites neglectus? Vigran, 1964. Sample CPW4, Slide NMW97.22G.3, E.F. No. H36/2, Mill Bay Formation, Cosheston Pill (west shore); (d) Emphanisporites obscurus McGregor, 1961. Sample CPW4, Slide NMW97.22G.2, E.F. No. R58/1, Mill Bay Formation, Cosheston Pill (west shore); 
polygonalis-emsiensis zone and these strata can therefore be correlated with the middle and upper part of the Senni Beds (Fig. 7).

Thus it seems likely that the deposits of the Senni Beds and Cosheston Group accumulated in different parts of the same basin at approximately the same time. It is therefore not surprising that strong lithological similarities exist between the deposits of the two stratigraphical units (see, for instance, R. Thomas, unpub. Ph.D. thesis, Univ. Bristol, 1978; Allen, Thomas \& Williams, 1982). However, thickness of the sedimentary sequence varies considerably with a much greater thickness of sediments accumulating in the region of southwest Wales. The breconensis-zavallatus zone is represented by less than 100 $m$ of strata in the Senni Beds of the Black Mountains and Brecon Beacons but by at least $265-340 \mathrm{~m}$ of strata in the Cosheston Group of southwest Wales. Similarly, the polygonalis-emsiensis zone is represented by at least $100-350 \mathrm{~m}$ of strata in the Senni Beds but at least $760-860 \mathrm{~m}$ of strata in the Cosheston Group. The greater thickness of strata in the Cosheston Group is not surprising since it is interpreted as accumulating in an area of complex relief with syn-depositional faulting (e.g. Allen \& Williams, 1978, 1982; Allen, 1985; Powell, 1987). The Senni Beds accumulated in part of the basin where there was presumably less subsidence and hiatuses are possibly of greater significance.

\section{4.b. Palaeoenvironmental interpretation}

The Cosheston Group palynomorph assemblages comprise entirely land-derived forms, apart from extremely rare marine palynomorphs (acritarchs and chitinozoans) which are almost certainly reworked. This strongly suggests that the Cosheston Group spore-bearing strata accumulated in a non-marine environment. Thus evidence from palynofacies analysis supports interpretations based on sedimentological considerations suggesting that these deposits are non-marine and accumulated in a continental fluviatile environment. Both the Cosheston Group (R. Thomas, unpub. Ph.D. thesis, Univ. Bristol, 1978; Allen, Thomas \& Williams, 1982) and the Senni Beds (Allen, 1979, 1985; Loeffler \& Thomas, 1980; Owen, 1995) are believed to have been deposited by a system of braided streams traversing an extensive alluvial plain.

\section{Palaeobotanical significance}

Historically, the floras of the Senni Beds have played a pivotal role in the palaeobotanical study of Lower Devonian land plants. In their classic monograph on the Senni Beds, Croft \& Lang (1942) provided detailed descriptions from a number of localities. As new material and techniques have become available this work has been substantially extended (Edwards, 1968, 1969a,b, 1980, 1981; Edwards \& Kenrick, 1986; Edwards et al. 1986; Edwards, Kenrick \& Carluccio, 1989; Kenrick \& Edwards, 1988a,b; Shute \& Edwards, 1989; Kenrick, Edwards \& Dales, 1991). The outcome is that plant megafossil assemblages from the Senni Beds provide one of the most comprehensive insights into Lower Devonian vegetation and their study mirrors historical developments in the study of Lower Devonian floras. Botanically they are important because of their diversity, both in terms of numbers of taxa and in their composition. The Allt Ddu assemblage in the Brecon Beacons provides evidence for a radiation of vascular plants, particularly zosterophylls, at the end of the Gedinnian (Fig. 7, locality $\mathrm{AD}$, breconensis-zavallatus Spore Assemblage Biozone), somewhat earlier than recorded elsewhere in the Old Red Sandstone continent. The succeeding Brecon Beacons assemblages contain the first record of both barinophytes (Krithodeophyton: Edwards, 1968) and trimerophytes (Dawsonites: Croft \& Lang, 1942).

(e) Emphanisporites zavallatus Richardson et al. 1982. Sample NN3, Slide NMW97.22G.6, E.F. No. P34/4; Llanstadwell Formation, Newton Noyes; (f) Emphanisporites micrornatus Richardson \& Lister, 1969. Sample NN15, Slide NMW97.22G.9, E.F. No. L61/3. Llanstadwell Formation, Newton Noyes; (g, h) Streelispora newportensis (Chaloner \& Streel) Richardson \& Lister, 1969. Sample NN3, Slide NMW97.22G.5, E.F. No. T34, Llanstadwell Formation, Newton Noyes. View of proximal and distal surface respectively; (i) Emphanisporites zavallatus Richardson et al. 1982. Sample WP25, Slide NMW97.22G.12, E.F. No. U32/4, Llanstadwell Formation, Wear Point; (j, k) Emphanisporites cf. decoratus Allen, 1965. Sample NN3, Slide NMW97.22G.7, E.F. No. Q22, Llanstadwell Formation, Newton Noyes. View of distal and proximal surface respectively; (1) Iberoespora sp. Sample WP25, Slide NMW97.22G.14, E.F. No. N49/3, Llanstadwell Formation, Wear Point; (m) Iberoespora sp. Sample MB8, Slide NMW97.22G.17, E.F. No. D50. Llanstadwell Formation, Muscle Bridge Quarry; (n) Breconisporites breconensis Richardson et al. 1982. Sample WP25, Slide NMW97.22G.15, E.F. No. E59, Llanstadwell Formation, Wear Point; (o) Breconisporites breconensis Richardson et al. 1982. Sample WP25, Slide NMW97.22G.10, E.F. No. N37, Llanstadwell Formation, Wear Point; (p) Breconisporites breconensis Richardson et al. 1982. Sample WP25, Slide NMW97.22G.15, E.F. No. E52, Llanstadwell Formation, Wear Point; (q) Amicosporites streelii Steemans, 1989. Sample WP25, Slide NMW97.22G.12, E.F. No. E30/2. Llanstadwell Formation, Wear Point; (r) cf. Camptozonotriletes caperatus McGregor, 1973. Sample CPW10, Slide NMW97.22G.4, E.F. No. T61/4, Mill Bay Formation, Cosheston Pill (west shore); (s) Archaeozonotriletes chulus (Cramer) Richardson \& Lister, 1969. Sample WP25, Slide NMW97.22G.11, E.F. No. M17/3, Llanstadwell Formation, Wear Point; (t,y) Chelinospora sp. Sample CPW10, Slide NMW97.22G.4, E.F. No. S40, Mill Bay Formation, Cosheston Pill (west shore) Proximal and distal surface respectively; (u) Camptozonotriletes cf. aliquantus Allen, 1965. Sample CPW4, Slide NMW97.22G.2, E.F. No. R27/1, Mill Bay Formation, Cosheston Pill (west shore); (v) Clivosispora verrucata McGregor, 1973. Sample WP25, Slide NMW97.22G.16, E.F. No. U39/1, Llanstadwell Formation, Wear Point; (x) Clivosispora verrucata McGregor, 1973. Sample CPW4, Slide NMW97.22G.1, E.F. No. N23, Mill Bay Formation, Cosheston Pill (west shore). 


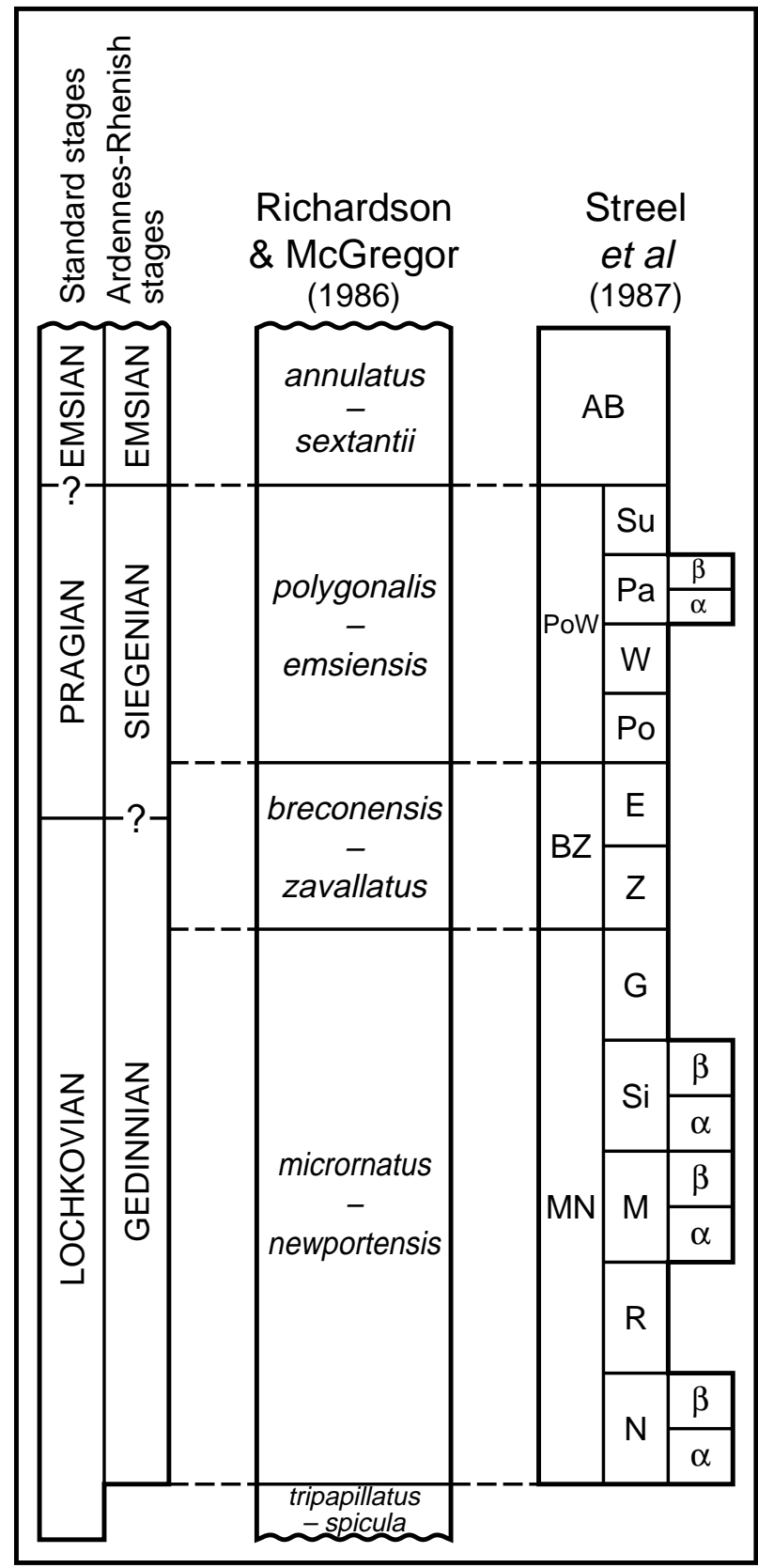

Figure 6. Correlation of spore zonal schemes with Lower Devonian stages. The scheme of Richardson \& McGregor (1986) uses spore assemblage biozones. The scheme of Streel et al. (1987) uses oppel zones (left hand column) and interval zones (right hand column(s)).

Furthermore, pyrite permineralization in the Brecon Beacons quarry assemblage (Fig. 7, locality BBQ) permits detailed examination of the three-dimensional anatomy of early vascular plants, particularly zosterophylls (e.g. Gosslingia: Kenrick \& Edwards, 1988a). Whether or not these are the oldest permineralizations yet known remains conjectural as precise correlation with the Rhynie Chert silicified plants (dated palynologically as Pragian and radiometrically via ${ }^{40} \mathrm{Ar}-{ }^{39} \mathrm{Ar}$ as $396 \pm 12$ Ma: Rice et al. 1995) is not possible.

The presence of plant megafossils in the Cosheston Group was noted by Strahan et al. (1914) and Cantrill et al. (1916), who could not identify the plants unequivocally and questionably assigned them to Psilophyton. Thomas (R. Thomas, unpub. Ph.D. thesis, Univ. Bristol, 1978) recorded the occurrence of plant megafossils in the Cosheston Group and reported that they were most abundant in the Llanstadwell Formation, common in the Burton Cliff Formation and lower part of the Mill Bay Formation, rare in the upper part of the Mill Bay Formation and the Lawrenny Cliff Formation, and absent from the New Shipping Formation. Thomas identified Zosterophyllum llanoveranum Croft \& Lang, 1942, from the Llanstadwell Formation at Muscle Bridge Quarry and ?Psilophyton sp. and an unidentified zosterophyll from the Mill Bay Formation at Mill Bay West. He also noted that Pachytheca and Prototaxites were commonly associated with plant debris preserved at a number of horizons in the Cosheston Group. Kenrick (P. Kenrick, unpub. Ph.D. thesis, Univ. Wales, 1988) undertook a systematic search for plant megafossils in the Cosheston Group and provided detailed description of the anatomy and morphology of some of the plants. His findings confirmed previous reports of the distribution of plant megafossils in the Cosheston Group, that is, they are abundant in the lower part of the group (Llanstadwell, Burton Cliff and Mill Bay formations) and rare in the upper (Lawrenny Cliff and New Shipping formations). Kenrick recorded five plant-bearing localities (Table 4) and a list of the taxa reported is presented in Table 5 (P. Kenrick, unpub. Ph.D. thesis, Univ. Wales, 1988, with additional information from Edwards, Kenrick \& Carluccio, 1989, and Kenrick, Edwards \& Dales, 1991). Edwards, Kenrick \& Carluccio (1989) published a detailed description of the zosterophyll Deheubarthia splendens Edwards, Kenrick \& Carluccio, 1989, which occurs in the Llanstadwell and Mill Bay formations, and Kenrick, Edwards \& Dales (1991) described the anatomy of specimens of Sennicaulis hippocrepiformis Edwards, 1981, from the Mill Bay Formation. Both of these taxa have also been reported from the Senni Beds (see Table 5).

The plant assemblages of the Cosheston Group are less diverse than those of the Senni Beds but demonstrate the widespread occurrence of Deheubarthia splendens, Gosslingia breconensis, Zosterophyllum llanoveranum, $Z$. cf. fertile and Sennicaulis hippocrepiformis on part of the southern margin of the Old Red Sandstone Continent in the Pragian (Siegenian). Anatomically they provide important information on the ultrastructure of a novel type of tracheid (S-type sensu Kenrick \& Crane, 1991; Kenrick, Edwards \& Dales, 1991), subsequently recognized as one of the distinguishing characters of a new grouping of early vascular plants (the Rhyniopsida) which includes Rhynia gwynne-vaughanii (Kenrick \& Crane, 1991). However, their usefulness in evolutionary and phytogeographical studies has been constrained by the absence of secure age determination and lack of detailed stratigraphical correlation of the Pembrokeshire sequences. The new spore data provide reliable age determinations for the Cosheston Group plant megafossil 


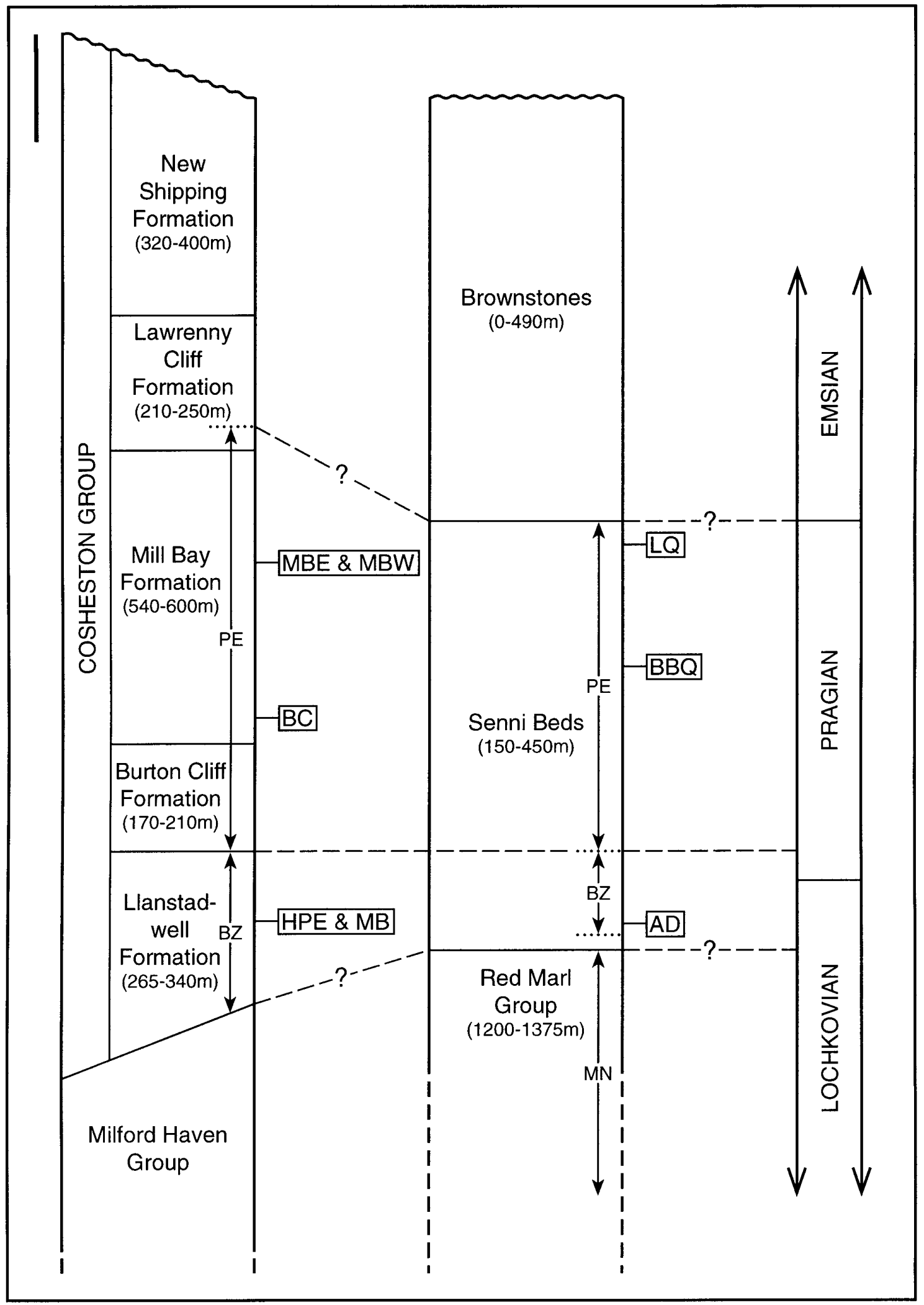

Figure 7. Correlation of the Cosheston Group and Senni Beds indicating the distribution of spore assemblage biozones and the location of plant megafossil assemblages. Regarding spore asemblage biozones ( $\mathrm{SAB}$ ): $\mathrm{MN}=$ micrornatus - newportensis $\mathrm{SAB} ; \mathrm{BZ}=$ breconensis-zavallatus $\mathrm{SAB} ; \mathrm{PE}=$ polygonalis-emsiensis $\mathrm{SAB}$. Regarding plant megafossil localities and their relative stratigraphical positions: AD = Allt Ddu; BBQ = Brecon Beacons (Storey Arms) Quarry; LQ = Llanover Quarry; CD = Craig Ddu; MB =Muscle Bridge Quarry; HPE = Hobbs Point East (east of Cheddar Bridge Pier); BC = Burton Cliff (foreshore at Williamson Mountain); MBW = Mill Bay West; MBE = Mill Bay East (references regarding palaeobotanical studies of the Cosheston Group localities are provided in Table 4). Note that the vertical scale for the stratigraphical columns differs. The verticle scale bar (top left-hand corner) represents $200 \mathrm{~m}$ for the Cosheston Group and $100 \mathrm{~m}$ for the Senni Beds. 
Table 4. Locality details for plant megafossil assemblages (see Fig. 3)

\begin{tabular}{|c|c|c|c|}
\hline Locality & Formation & Grid reference & Location \\
\hline Muscle Bridge Quarry (MB) & Llanstadwell Fm. & SM95650558 & $\begin{array}{l}\text { Disused quarry located beside the B425 road c.250m SE of Muscle } \\
\text { Bridge Hamlet. See Thomas in Friend and Williams (1978), } \\
\text { R. Thomas (unpub. Ph.D. thesis, Univ. Bristol, 1978), P. Kenrick } \\
\text { (unpub. Ph.D. thesis, Univ. Wales, 1988) and Edwards, Kenrick } \\
\text { \& Carluccio (1989). }\end{array}$ \\
\hline Hobbs Point East (HPE) & Llanstadwell Fm. & SM973044 & $\begin{array}{l}\text { Exposure in coastal section c. } 200 \mathrm{~m} \text { east of Cheddar Bridge Pier. } \\
\text { See P. Kenrick (unpub. Ph.D. thesis, Univ. Wales, 1988). }\end{array}$ \\
\hline Burton Cliff (BC) & Mill Bay Fm. & SN99110532 & $\begin{array}{l}\text { Exposure in coastal section at Burton Cliff (foreshore at Williamson } \\
\text { Mountain). See P. Kenrick (unpub. Ph.D. thesis, Univ. Wales, } \\
\text { 1988) and Edwards, Kenrick \& Carluccio (1989). }\end{array}$ \\
\hline Mill Bay West (MBW) & Mill Bay Fm. & c. SN002049 & $\begin{array}{l}\text { Several plant beds occur in the coastal section exposed to the west of } \\
\text { Mill Bay inlet. See Thomas in Friend \& Williams (1978), } \\
\text { P. Kenrick (unpub. Ph.D. thesis, Univ. Wales, 1988) and Kenrick, } \\
\text { Edwards \& Dales (1991). }\end{array}$ \\
\hline Mill Bay East (MBE) & Mill Bay Fm. & c. SN005051 & $\begin{array}{l}\text { Several plant beds occur in the coastal section exposed to the east of } \\
\text { Mill Bay inlet. See P. Kenrick (unpub. Ph.D. thesis, Univ. Wales, } \\
\text { 1988). }\end{array}$ \\
\hline
\end{tabular}

Table 5. Distribution of plant megafossil taxa reported from the Senni Beds and Cosheston Group

\begin{tabular}{|c|c|c|c|c|c|c|c|c|c|}
\hline \multirow[b]{3}{*}{ Taxa } & \multicolumn{9}{|c|}{ Localities } \\
\hline & \multicolumn{4}{|c|}{ Senni Beds } & \multicolumn{5}{|c|}{ Cosheston Group } \\
\hline & $\mathrm{AD}^{\mathrm{BZ}}$ & $\mathrm{BBQ}^{\mathrm{PE}}$ & $\mathrm{LQ}^{-}$ & $\mathrm{CD}^{-}$ & $\mathrm{MB}^{\mathrm{BZ}}$ & $\mathrm{HPE}^{\mathrm{BZ}}$ & $\mathrm{BC}^{\mathrm{PE}}$ & $\mathrm{MBW}^{\mathrm{PE}}$ & $\mathrm{MBE}^{\mathrm{PE}}$ \\
\hline Nematothallus sp. & & $\mathrm{X}$ & $\mathrm{X}$ & & & & & & \\
\hline Pachytheca sp. & & $\mathrm{X}$ & $\mathrm{X}$ & & $\mathrm{X}$ & $X$ & $X$ & $\mathrm{X}$ & $\mathrm{X}$ \\
\hline Prototaxites sp. & & $\mathrm{X}$ & $\mathrm{X}$ & & $\mathrm{X}$ & $X$ & $\mathrm{X}$ & $\mathrm{X}$ & $\mathrm{X}$ \\
\hline cf. Cooksonia & $?$ & & & $\mathrm{X}$ & & & $\mathrm{X}$ & & \\
\hline Salopella allenii & $\mathrm{X}$ & & & & & & & & \\
\hline cf. Salopella & & & & $\mathrm{X}$ & & $\mathrm{X}$ & & & \\
\hline Sporogonites exuberans Halle & & & $\mathrm{X}$ & & & & & & \\
\hline Taeniocrada sp. & & & $\mathrm{X}$ & & & & & & \\
\hline Renalia & $?$ & & & & & & & & \\
\hline Uskiella spargens Shute \& Edwards & & $\mathrm{X}$ & $\mathrm{X}$ & & & & & & \\
\hline Unidentified Rhyniophyte & $\mathrm{X}$ & & & & & $\mathrm{X}$ & $\mathrm{X}$ & & \\
\hline Deheubarthia splendens Edwards et al. & $X$ & $\mathrm{X}$ & $X$ & $?$ & $\mathrm{X}$ & & $\mathrm{X}$ & & \\
\hline Gosslingia breconensis Heard & $\mathrm{X}$ & $\mathrm{X}$ & $\mathrm{X}$ & & & & $X$ & & $\mathrm{X}$ \\
\hline Thrinkophyton formosum Kenrick \& Edwards & $?$ & & & $\mathrm{X}$ & & & & & \\
\hline Z. cf. australianum Lang \& Cookson & & & $\mathrm{X}$ & & & & & & \\
\hline Z. cf. fertile Leclercq & $\mathrm{X}$ & $\mathrm{X}$ & $X$ & & $\mathrm{X}$ & & $\mathrm{X}$ & & \\
\hline Zosterophyllum llanoveranum Croft \& Lang & & $\mathrm{X}$ & $\mathrm{X}$ & & $\mathrm{X}$ & & & & \\
\hline cf. Zosterophyllum & & & & & & & $\mathrm{X}$ & & \\
\hline Drepanophycus spinaeformis Goppert & & $\mathrm{X}$ & $\mathrm{X}$ & & & & & & \\
\hline Dawsonites arcuatus Halle & & $\mathrm{X}$ & $\mathrm{X}$ & & & & & & \\
\hline cf. Dawsonites & & & & & & & $\mathrm{X}$ & & \\
\hline Krithodeophyton croftii Edwards & & $\mathrm{X}$ & & & & & & & \\
\hline Hostinella heardii Edwards & & $\mathrm{X}$ & & & & & & & \\
\hline Sciadophyton cf. steinmanii Krausel \& Weyland & & & $\mathrm{X}$ & & & & & & \\
\hline Sennicaulis hippocrepiformis Edwards & $?$ & $\mathrm{X}$ & $\mathrm{X}$ & & & & & $\mathrm{X}$ & \\
\hline cf. Taitia & & $\mathrm{X}$ & & & & & & & \\
\hline Tarella trowenii Edwards \& Kenrick & & $\mathrm{X}$ & & & & & & & \\
\hline
\end{tabular}

Regarding localities: AD = Allt Ddu: Senni Beds (Edwards, Kenrick \& Carluccio, 1989; Edwards, 1990); BBQ = Brecon Beacons (Storey Arms) Quarry: Senni Beds (Mortimer, 1967; Edwards, 1968; Edwards \& Richardson in Friend \& Williams, 1978; Edwards et al. 1986; Edwards, Kenrick \& Carluccio, 1989; Kenrick \& Edwards, 1988a); LQ = Llanover Quarry: Senni Beds (Croft \& Lang, 1942; Mortimer, 1967; Richardson \& Lister, 1969; Edwards, Kenrick \& Carluccio, 1989; Shute \& Edwards, 1989); CD = Craig Ddu: Senni Beds (Kenrick \& Edwards, 1988b; Owen, 1995); MB = Muscle Bridge Quarry: Llanstadwell Fm., Cosheston Gp. (Thomas in Friend \& Williams, 1978; Thomas unpub. Ph.D. thesis, Univ. Bristol, 1978; P. Kenrick, unpub. Ph.D. thesis, Univ. Wales, 1988; Edwards, Kenrick \& Carluccio, 1989); HPE = Hobbs Point East (east of Cheddar Bridge Pier): Llanstadwell Fm., Cosheston Gp. (Thomas unpub. Ph.D. thesis, Univ. Bristol, 1978; P. Kenrick unpub. Ph.D. thesis, Univ. Wales, 1988); BC = Burton Cliff (foreshore at Williamston Mountain): Mill Bay Fm., Cosheston Gp. (R. Thomas unpub. Ph.D. thesis, Univ. Bristol, 1978; P. Kenrick, unpub. Ph.D. thesis, Univ. Wales, 1988; Kenrick, Edwards \& Dales, 1991). MBW = Mill Bay West: Mill Bay Fm., Cosheston Gp. (Thomas in Friend \& Williams, 1978; R. Thomas, unpub. Ph.D. thesis, Univ. Bristol, 1978; P. Kenrick, unpub. Ph.D. thesis, Univ. Wales, 1988; Edwards, Kenrick \& Carluccio, 1989); MBE = Mill Bay East: Mill Bay Fm., Cosheston Gp. (R. Thomas, unpub. Ph.D. thesis, Univ. Bristol, 1978; P. Kenrick, unpub. Ph.D. thesis, Univ. Wales, 1988); BZ = breconensis-zavallatus Spore Assemblage Biozone; $\mathrm{PE}=$ polygonalis-emsiensis Spore Assemblage Biozone; $-=$ no spore data. 
assemblages and allow correlation with those from the Senni Beds.

Acknowledgements. The work on dispersed spores was initially undertaken by RGT during the tenure of a NERC funded research studentship conducted in the Department of Botany and the Department of Geology of the University of Bristol. RGT wishes to thank his supervisors, Dr Keith Allen and Prof. Brian Williams, for their guidance and friendship. CHW would like to thank Dr Keith Allen for making the material available for further study and the Leverhulme Trust who funded his postdoctoral research. Megafossils were described by PK whilst financed by NERC Research Grant no. GR3/5069.

\section{References}

Allen, K. C. 1965. Lower and Middle Devonian spores of North and Central Vestspitsbergen. Palaeontology 8, 687-748.

Allen, J. R. L. 1979. Old Red Sandstone facies in external basins, with particular reference to southern Britain. Special Papers in Palaeontology 23, 65-80.

Allen, J. R. L. 1985. Marine to freshwater: the sedimentology of the interrupted environmental transition (LudlowSiegenian) in the Anglo- Welsh region. Philosophical Transactions of the Royal Society of London 309B, 85-104.

Allen, J. R. L., Thomas, R. G. \& Williams, B. P. J. 1982. The Old Red Sandstone North of Milford Haven. In Geological excursions in Dyfed, southwest Wales (ed. M. G . Bassett), pp. 123-49. National Museum of Wales Publication.

Allen, J. R. L. \& Williams, B. P. J. 1978. The sequence of the earlier Lower Old Red Sandstone (Siluro-Devonian), north of Milford Haven, southwest Dyfed, Wales. Geological Journal 13, 113-36.

Allen, J. R. L. \& Williams, B. P. J. 1981. Sedimentology and stratigraphy of the Townsend Tuff Bed (Lower Old Red Sandstone) in South Wales and the Welsh Borders. Journal of the Geological Society, London 138, 15-30.

Allen, J. R. L. \& Williams, B. P. J. 1982. The architecture of an alluvial suite: rocks between the Townsend Tuff and Pickard Bay Tuff Beds (early Devonian), southwest Wales. Philosophical Transactions of the Royal Society of London 297B, 51-89.

Bluck, B. J., Cope, J. W. C. \& Scrutton, C. T. 1992. Devonian. In Atlas of Palaeogeography and Lithofacies (eds J. C. W. Cope, J. K. Ingham and P. F. Rawson), pp. 57-66. Geological Society of London Memoir no. 13.

Cantrill, T. C., Dixon, E. E. L., Thomas, H. H. \& Jones, O. T. 1916. The geology of the South Wales Coalfield. Part XII. The country around Milford. Memoir, Geological Survey of Great Britain, 185.

Croft, W. N. \& LANG, W. H. 1942. The Lower Devonian flora of the Senni Beds of Monmouthshire and Breconshire. Philosophical Transactions of the Royal Society of London 231B, 131-63.

Dixon, E. E. L. 1921. The geology of the South Wales Coalfield. Part XIII. The country around Pembroke and Tenby. Memoir, Geological Survey of Great Britain, 220.

Dixon, E. E. L. 1933a. Some recent stratigraphical work and its bearing on south Pembrokeshire problems. Proceedings of the Geological Association 44, 217-25.

Dixon, E. E. L. 1933b. Notes on the geological succession in south Pembrokeshire. Proceedings of the Geological Association 44, 402-11.
EDWARDS, D. 1968. A new plant from the Lower Old Red Sandstone of South Wales. Palaeontology 11, 683-90.

EDWARDS, D. 1969a. Further observations on Zosterophyllum llanoveranum from the Lower Devonian of South Wales. American Journal of Botany 56, 201-10.

EDWARDS, D. 1969b. Zosterophyllum from the Lower Old Red Sandstone of South Wales. New Phytologist 68, 923-31.

EDWARDS, D. 1980. Studies on Lower Devonian petrifactions from Britain. 1. Pyritised axes of Hostinella from the Brecon Beacons Quarry, Powys, South Wales. Review of Palaeobotany and Palynology 29, 189-200.

EDWARDS, D. 1981. Studies on Lower Devonian petrifactions from Britain. 2. Sennicaulis, a new form genus for sterile axes based on pyrite and limonite petrifactions from the Senni Beds. Review of Palaeobotany and Palynology 32, 207-26.

EDWARDS, D. 1990. Constraints on Silurian and Early Devonian phytogeographic analysis based on megafossils. In Palaeozoic Palaeogeography and Biogeography (eds W. S. McKerrow and C. R. Scotese), pp. 233-42. Geological Society of London Memoir no. 12.

EDWARDS, D. \& KenRICK, P. 1986. A new zosterophyll from the Lower Devonian of Wales. Botanical Journal of the Linnean Society 92, 269-83.

Edwards, D., KenRick, P. \& CARluccio, L. M. 1989. A reconsideration of cf. Psilophyton princeps (Croft and Lang, 1942), a zosterophyll widespread in the Lower Old Red Sandstone of South Wales. Botanical Journal of the Linnean Society 100, 293-318.

Edwards, D., Rose, V., AXe, L. \& Kenrick, P. 1986. Studies on Lower Devonian petrifactions from Britain, 3. Notes on putative fungal remains in zosterophylls from the Brecon Beacons, Powys, South Wales. Review of Palaeobotany and Palynology 48, 241-51.

FRIEND, P. F. \& WILLIAMs, B. P. J. 1978. A field guide to selected outcrop areas of the Devonian of Scotland, the Welsh Borderland and South Wales. The Palaeontological Association.

Kenrick, P. \& Crane, P. R. 1991. Water-conducting cells in early fossil land plants: implications for the early evolution of Tracheophytes. Botanical Gazette 152, 335-56.

KenRICK, P. \& EDWARDS, D. 1988a. The anatomy of Lower Devonian Gosslingia breconensis Heard based on pyritised axes, with some comments on the permineralisation process. Botanical Journal of the Linnean Society 97, 95-123.

KENRICK, P. \& EDWARDS, D. 1988b. A new zosterophyll from a recently discovered exposure of the Lower Devonian Senni Beds in Dyfed, Wales. Botanical Journal of the Linnean Society 98, 97-115.

KENRICK, P., EdWARDS, D. \& DALES, R. C. 1991. Novel ultrastructure in water-conducting cells of the Lower Devonian plant Sennicaulis hippocrepiformis. Palaeontology 34, 751-66.

KING, W. W. 1934. The Downtonian and Dittonian strata of Great Britain and Northwestern Europe. Quarterly Journal of the Geological Society of London 90, 526-70.

LANNINGER, E. P. 1968. Sporen-Gesellschaften aus dem Ems der SW-Eifel. Palaeontographica 122B, 95-170.

LOEFFLER, E. J. \& THOMAS, R. G. 1980. A new pteraspidid ostracoderm from the Devonian of the Senni Beds Formation of South Wales and its stratigraphic significance. Palaeontology 23, 287-96.

MCGREGOR, D. C. 1961. Spores with proximal radial pattern from the Devonian of Canada. Geological Survey of Canada Bulletin 76, 1-11.

McGregor, D. C. 1973. Lower and Middle Devonian spores of Eastern Gaspé, Canada. Palaeontographica 142B, 1-77. 
MCGREGoR, D. C. \& CAmField, M. 1976. Upper Silurian? to Middle Devonian spores of the Moose River basin, Ontario. Geological Survey of Canada Bulletin 263, 1-63.

Mortimer, M. G. 1967. Some Lower Devonian microfloras from southern Britain. Review of Palaeobotany and Palynology 1, 95-109.

Owen, G. 1995. Senni Beds of the Devonian Old Red Sandstone, Dyfed, Wales: anatomy of a semi-arid floodplain. Sedimentary Geology 95, 221-35.

Owen, T. R., Bloxam, T. W., Jones, D. G., Walmsley, V. G. \& Williams, B. P. J. 1971. Summer (1968) field meeting in Pembrokeshire, South Wales. Proceedings of the Geologists Association 82, 17-60.

Powell, C. M. 1987. Inversion tectonics in S. W. Dyfed. Proceedings of the Geological Association 98, 193-203.

Rice, C. M., Ashcroft, W. A., Batten, D. J., Boyce, A. J., Caulfield, J. B. D., Fallick, A. E., Hole, M. J., Jones, E., Pearson, M. J., Rogers, G., SAXton, J. M., Stuart, F. M., Trewin, N. H. \& TURner, G. 1995. A Devonian auriferous hot spring system, Rhynie, Scotland. Journal of the Geological Society, London 152, 229-50.

RICHARDSON, J. B. 1984. Mid-Palaeozoic palynology, facies and correlation. Proceedings of the 27th International Geological Congress 1, 341-65.

Richardson, J. B., Ford, J. H. \& PARKER, F. 1984. Miospores, correlation and age of some Scottish Lower Old Red Sandstone sediments from the Strathmore region (Fife and Angus). Journal of Micropalaeontology 3, 109-24.

RichaRdson, J. B. \& ListeR, T. R. 1969. Upper Silurian and Lower Devonian spore assemblages from the Welsh Borderland and South Wales. Palaeontology 12, 201-52.

Richardson, J. B. \& McGregor, D. C. 1986. Silurian and Devonian spore zones of the Old Red Sandstone continent and adjacent areas. Geological Survey of Canada Bulletin 364, 1-79.

Richardson, J. B., Rasul, S. M. \& Al-Ameri, T. 1981. Acritarchs, miospores and correlation of the LudlovianDowntonian and Silurian- Devonian boundaries. Review of Palaeobotany and Palynology 34, 209-24.

Richardson, J. B., Streel, M., Hassan, A. \& Steemans, P. 1982. A new spore assemblage to correlate between the Breconian (British Isles) and the Gedinnian (Belgium). Annales de la Société Géologique de Belgique $\mathbf{1 0 5}$, 135-43.

ShUTE, C. H. \& EDWARDS, D. 1989. A new rhyniopsid with novel sporangium organisation from the Lower Devonian of South Wales. Botanical Journal of the Linnean Society 100, 111-37.

Steemans, P. 1989. Etude palynostratigraphique du Devonien Inferieur dans l'ouest del'Europe. Mémoires pour servir à l'Eplication des Cartes Geologiques et Minières de la Belgique. Memoir no. 27. 453 pp.

Strahan, A., Cantrill, T. C., Dixon, E. E. L., Thomas, H. H. \& JONES, O. T. 1914. The geology of the South Wales Coalfield. Part XI. The country around Haverfordwest. Memoir, Geological Survey of Great Britain, 262.

Streel, M. 1964. Une association de spores du Givétian Inférieur de la Vesdre, a Goé (Belgique). Annales de la Société Géologique de Belgique 87, 233-62.

StreEl, M. 1967. Associations de spores du Dévonien Inferieur Belge et leur signification stratigraphique. Annales de la Société Géologique de Belgique 90, 11-54.

Streel, M., Higgs, K., Loboziak, S., Riegel, W. \& Steemans, P. 1987. Spore stratigraphy and correlation with faunas and floras in the type marine Devonian of the Ardenne-Rhenish regions. Review of Palaeobotany and Palynology 50, 211-29.

Vigran, J. O. 1964. Spores from Devonian deposits, Mimerdalen, Spitsbergen. Norsk Polarinstitutt Skrifter 132, 1-32.

White, E. I. 1938. New Pteraspids from South Wales. Quarterly Journal of the Geological Society of London 94, 85-115.

White, E. I. 1946. The genus Phialaspis and the 'Psammosteus' Limestones. Quarterly Journal of the Geological Society of London 101, 207-42.

White, E. I. 1950. Pteraspis leathensis White, a Dittonian zonefossil. Bulletin of the British Museum (Natural History), Geology Series 1, 69-89.

Williams, B. P. J. 1971. Sedimentary features of the Old Red Sandstone and Lower Limestone Shales of south Pembrokeshire, south of the Ritec fault. In Excursions in South Wales and the Forest of Dean (eds D. M. Bassett and M. G. Bassett), pp. 222-39. Geologists Association, South Wales Group, Cardiff.

Williams, B. P. J., Allen, J. R. L. \& Marshall, J. D. 1982. Old Red Sandstone facies of the Pembroke Peninsula, south of the Ritec Fault. In Geological excursions in Dyfed, southwest Wales (ed. M. G . Bassett), pp. 151-74. National Museum of Wales Publication, Cardiff. 